\title{
A REVISION OF THE GENUS LINDBERGIA (LESKEACEAE, BRYOPHYTA) IN RUSSIA
}

\section{РЕВИЗИЯ РОДА LINDBERGIA (LESKEACEAE, ВRYOPHYTA) В РОССИИ}

\author{
E.A. IGNATOVA ${ }^{1}$, M.S. IGNATOV ${ }^{2} \&$ I.A. MiLYUTINA ${ }^{3}$ \\ Е.А. ИГНАТОВА ${ }^{1}$, М.С. ИГНАТОВ ${ }^{2} \&$ И.А. МИЛЮТИНА ${ }^{3}$
}

Abstract

The genus Lindbergia is subdivided into 3 groups basing on morphological and molecular characters, and all these groups are represented in Russia. Lindbergia brachyptera is excluded from the Russian moss flora, it likely occurs only in North America; Russian plants referred to it belong to a closely related L. grandiretis. Specimens reported from the Russian Far East as Lindbergia duthiei and L. japonica are re-identified as L. sinensis. Mamillariella, a monospecific genus, is the closest relative to L. sinensis and is transferred to Lindbergia. Lindbergia dagestanica Ignatova \& Ignatov sp. $\mathrm{n}$. is described from the East Caucasus; this species is closely related to the American L. mexicana and African L. patentifolia. Plants of the latter group have never been reported from Eurasia before.

Резюме

По данным морфологического и молекулярно-филогенетического анализа род Lindbergia подразделен на 3 группы, причем все они представлены во флоре России. Lindbergia brachyptera исключена из флоры России, вероятно, она растет только в Северной Америке, а так определявшиеся растения с Кавказа и из Сибири относятся к близкому виду L. grandiretis. Образцы с Дальнего Востока, определявшиеся как L. duthiei и L. japonica, отнесены к L. sinensis. Mamillariella, монотипный род, очень близок к L. sinensis и переведен в род Lindbergia. Из Дагестана описан новый вид Lindbergia dagestanica Ignatova \& Ignatov sp. n., близкородственный американской L. mexicana и африканской L. patentifolia. Представители последней группы ранее в Евразии известны не были.

KEYWORDS: Lindbergia, molecular phylogeny, mosses, peristome, Russia

INTRODUCTION

Lindbergia is a relatively small genus that has never been revised worldwide since Brotherus' treatment in "Die Naturlichen Pflanzenfamilien" (1925). At the same time, various regional treatments often described local species without sufficient comparison with other territories, so our study of the genus in Russia urged necessity of a revision in a broader scope.
The first finding of Lindbergia in Russia was made by V.F. Brotherus in the Caucasus. The specimen was described as Leskea grandiretis by S.O.Lindberg in Brotherus" "Musci Caucasici" (1892). Later this species was synonymized with Lindbergia austinii (Sull.) Broth. (=L. brachyptera) by Holzinger (Bryologist 6: 75. 1903; cited by Wijk et al., 1964) and for a long time had not been accepted as a separate species until

1 - Moscow State University, Biological Faculty, Geobotany Dept., Moscow 119991 Russia - Россия 119991 Москва, Московский государственный университет, Биологический факультет, каф. геоботаники; arctoa@ list.ru

2 - Main Botanical Garden of Russian Academy of Sciences, Botanicheskaya 4, Moscow 127276 Russia Россия 127276 Москва, Ботаническая, 4, Главный ботанический сад PAH; misha ignatov@list.ru

3 - A. N. Belozersky Institute of Physico-Chemical Biology, Moscow State University, Moscow 119991 Russia - Россия, 119991 Москва, Московский государственный университет, Институт физико-химической биологии им. А.Н. Белозерского; iramilyutina@yandex.ru 
Ignatov, Afonina, Ignatova et al. (2006) resurrected it as an independent species, although without arguments, which we are going to present here.

Lazarenko (1941) reported L. japonica from Primorsky Territory of the Russian Far East, and this record was repeated without any revision in subsequent accounts of the Russian Far East bryoflora (Bardunov \& Cherdantseva, 1982) and checklists (e.g. Ignatov, Afonina, Ignatova \& al., 2006). Besides, Lazarenko (1934) described a monospecific genus Mamillariella from the same area, which was accepted by all subsequent authors in its original volume and status, including the revision of Buck (1980). The mamillose seta of this species is a unique character in the whole Leskeaceae, according to the traditional approach to the family. However, Gardiner et al. (2005) and Ignatov et al. (2007) have found in their molecular phylogenetic analyses that Mamillariella is closely related to Lindbergia duthiei (based on a specimen from the Russian Far East).

Bardunov (1969) reported from south Siberia, Transbaikalia L. brachyptera, the species described from eastern North America and then published for China by Levier (1906) and subsequent authors. Later on, Bardunov \& Cherdantseva (1982) reported from Primorsky Territory one more species of Lindbergia, L. duthiei, a species originally described from the Western Himalayas (Brotherus, 1898).

Our interest to the genus was raised when attempting to identify one inegmatic specimen from Dagestan, eastern part of the Caucasus near the Caspean Sea. This area has a quite xeric climate and many interesting xerophytic mosses, including Indusiella and Jaffueliobryum (see also Ignatov et al., 2010). After an expanded search, we found its surprizing subidentity with Lindbergia mexicana (Besch.) Cardot from North and South America, and with L. patentifolia Dixon from the South and East Africa. Their morphological similarity with the Caucasian plant left no doubts on their relationship, but raised the question on their generic position, as this group of species has a number of differencies from Lindbergia brachyptera, the type of the genus.

\section{MATERIAL AND METHODS}

Morphological studies include the material on Lindbergia from H, IRK, KW, LE, MW, MHA, S, SASY, VLA.
Peristomes were studied and photographed under Com Scan 2 SEM. Papillae were studied in both transmitted light and with fluorescence of the berberin stained specimens under Olympus $\mathrm{SX} 41, \lambda=488 \mathrm{~nm}$.

Molecular studies include the sequencing of nr ITS and cp trnL-F of Lindbergia, which were analyzed with data from the previous analysis of pleurocarps (Ignatov et al., 2007). This previous set was reduced, so mostly Leskeaceae species were retained. Specimen vouchers and GenBank accessions are in Appendix 1.

Laboratory protocol was essentially the same as in some of our previous analyses (e.g. Gardiner et al., 2005). Maximum parsimony analysis was performed in Nona (Goloboff, 1994) under Winclada shell (Nixon, 1999).

One $\operatorname{trn} \mathrm{L}-\mathrm{F}$ short inversion region of $3 \mathrm{nu}-$ cleotides exhibits strong variation (CCT - AGG), so it was omitted in the analysis according to the suggestion of Quandt \& Stech (2005).

\section{RESULTS}

ITS analysis. The Lindbergia s. ampl. species were resolved into three clades, each having a high support (Fig. 1 A). These three clades form a bigger clade, which includes also a widespread Australian species, Pseudoleskeopsis imbricata. The support of this bigger clade was found to be low, 57.

The three well supported clades are as follow: (1) L. brachyptera + L. grandiretis; (2) L. sinensis + Mamillariella geniculata; (3) L. mexicana + L. patentifolia; their jackknife support is 99, 85 and 98 correspondingly.

Strict consensus tree based on $\operatorname{trn} \mathrm{L}-\mathrm{F}$ (Fig. $1 \mathrm{~B})$ resolved Lindbergia species in one clade that includes also Pseudoleskeopsis imbricata (Fig. 1 B).

\section{DISCUSSION}

ITS tree provided topology that is in general congruent with those previously found in a number of analyses (Gardiner et al., 2005; Ignatov et al., 2007; Garci'a-Avila et al., 2009; Du et al., 2005).

The obtained topology raises the question if the three clades are better to treat as separate genera or infrageneric units of Lindbergia. There are pros and cons in both ways, but we are now inclined to keep a conservative approach, minimizing nomenclatural changes by a two following reasons. 


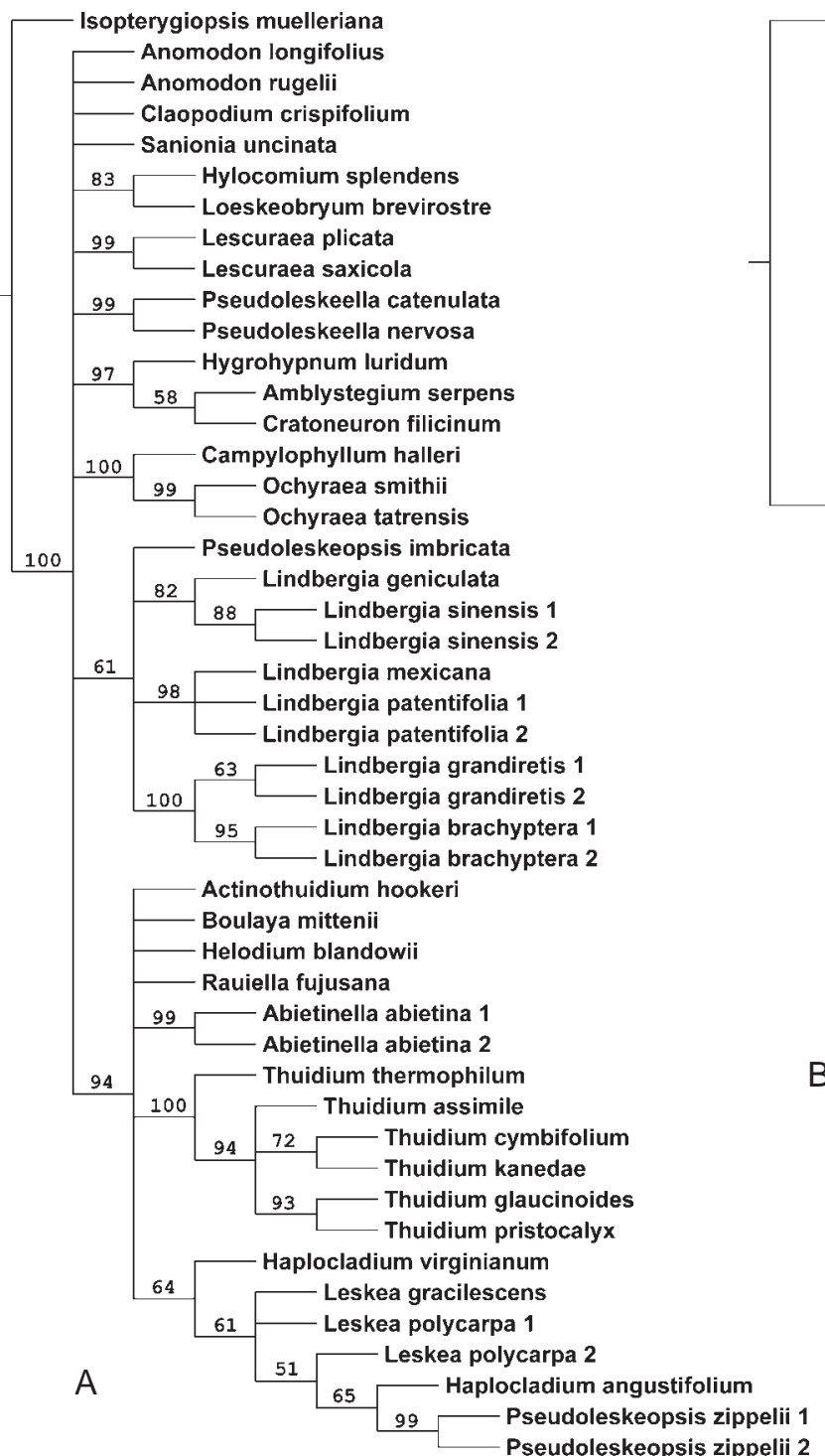

Isopterygiopsis muelleriana

Claopodium crispifolium

Climacium dendroides

Pseudoleskeella catenulata

Pseudoleskeella nervosa

Sanionia uncinata

Loeskeobryum brevirostre

Hylocomium splendens

Amblystegium serpens

Hygrohypnum luridum

Cratoneuron filicinum1

Lescuraea plicata

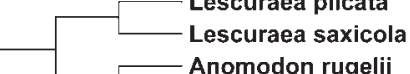

Anomodon rugeli

Anomodon longifolius

Campylophyllum halleri

Ochyraea smithii

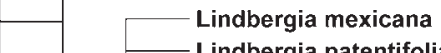

Lindbergia patentifolia

- Lindbergia sinensis 1

Pseudoleskeopsis imbricata

Lindbergia brachyptera 1

Lindbergia brachyptera 2

Lindbergia geniculata

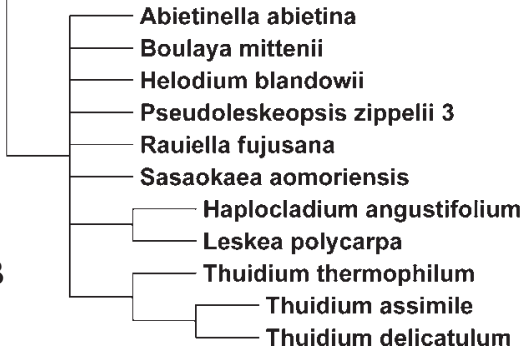

Fig. 1. A. Bootsrap tree based on ITS dataset; supports $>50$ calculated for 3000 replications are shown above branches

B. Results of phylogenetic analysis of trnL-F dataset. Strict consensus tree 588 shortest tree found in parsimony ratchet analysis, $\mathrm{L}=115 ; \mathrm{CI}=0.61, \mathrm{RI}=0.71$.

(1) Pseudoleskeopsis imbricata. This species is really distinct gametophytically from the $P$. zippellii, the type of the genus Pseudoleskeopsis, and it obviously needs a more natural placement. However, the simple transfer to Lindbergia would be premature, as there are a number of other probably related genera in South Hemisphere, not included in the present analysis. Especially this concerns Leskeadelphus, which affinity with the Pseudoleskeopsis has recently been found by Cox et al. (2010). Both Leskeadelphus and Pseudoleskeopsis imbricata have more or less complete peristomes with cross striolate exostome teeth (Buck, 1980). On the oth- er hand, there is a number of pleurocarpous genera where species with perfect and reduced peristomes occur, e.g. Homalothecium (Huttunen et al., 2008), Pylaisia (Arikawa, 2004), and in acrocarpous families such examples are far more numerous.

(2) Excepting Pseudoleskeopsis imbricata, there are no other genera appearing in between the three groups of Lindbergia. Thus their acceptance both as genera or subgenera could be admitted, the latter being better, as no nomenclatural changes will be in need.

Morphological differences of representatives of these three clades are as shown in Table 1. 
Table 1. A comparison of three groups of species in Lindbergia.

\begin{tabular}{llll} 
Leaf shape & $\begin{array}{l}\text { L. brachyptera-group } \\
\text { acuminate }\end{array}$ & $\begin{array}{l}\text { L. sinensis-group } \\
\text { acuminate }\end{array}$ & $\begin{array}{l}\text { L. mexicana-group } \\
\text { acute to acuminate }\end{array}$ \\
Acumen looks & thyaline & green & green \\
Leaf margin & entire & entire & serrulate \\
Leaf papillae & large, simple to forked & \multicolumn{1}{c}{ small and indistinct to absent } \\
Seta & smooth & smooth or rough & smooth \\
Capsule shape & ovate & ovate & cylindrical \\
Segments & absent & absent & absent to present \\
Basal membrane & present & present or absent & present \\
Teeth outside & weakly to & strongly papillose & moderately papillose \\
& moderately papillose & & to smooth \\
\hline
\end{tabular}

\section{TAXONOMY}

Lindbergia Kindb., Gen. Eur. N. Amer. Bryin. 15. 1897.

Plants slender, dull, green, olivaceous or brownish, in thin mats. Stems creeping, irregularly or \pm pinnately branching. Stem and branch leaves similar, crowded, appressed and imbricate when dry, widely spreading when moist, ovate or ovate-lanceolate, acute or acuminate, slightly concave, shortly decurrent; margins plane, entire or serrulate; costa single, stout, reaching 2/3-3/4 the leaf length or percurrent; lamina smooth or papillose on both sides, papilla single per cell on each side, simple or forked; upper and median laminal cells \pm isodiametric, rounded, shortly ovate or rombic and short rectangular, with thin or moderately thickened walls, with corner thickenings; basal juxtacostal cells not differentiated; basal marginal cells in 4-10 oblique rows transversely ovate, gradually transiting to isodiametric median cells. Autoicous. Perichaetial leaves pale, erect, long-acuminate from a sheathing base, not plicate, costa short, indistinctly delimited, cells rectangular, smooth. Setae erect, smooth or mamillose. Capsules oblong-cylindrical, erect and symmetric or slightly asymmetric, narrowed to the mouth. Peristome double, inserted well below the mouth; exostome teeth lanceolate, smooth or papillose; endostome absent or present, consisting of low, smooth or papillose basal membrane, segments absent or present, narrow and fragile. Operculum low conic, with short, straight or curved obtuse beak. $\mathrm{Ca}$ lyptrae cucullate, naked.

Lindbergia grandiretis (Lindb. ex Broth.) Ignatov \& Ignatova, Arctoa 15: 49. 2006. - Leskea grandiretis Lindb. ex Broth., Acta Soc. Sci. Fenn. 19(12): 97.1892.

Figs. 2-3; 4: 5-7; 8: 5-9
Lectotype (selected here): "Leskea grandiretis Lindb. n. sp., Caucasus: Balta ad fl. Terek, 19/5 1881, leg. V.F. Brotherus" (H-BR 2483003!; isotype in LE, small difference in date is: "V.1881"); Syntypes (same label as lectotype, HBR 2483002! [scanty specimen]); Lars ad fl. Terek, 28/5 1881 leg. V.F. Brotherus" H-BR 2483004 ! [without sporophytes]). Lectotype is selected as the most representative collection.

Plants dull green, olivaceous or brownish green, in thin mats or growing as admixture to other bryophytes. Stems to $4 \mathrm{~cm}$ long, pinnately or irregularly pinnately branching, branches arcuate, 2-5 mm long. Stem and branch leaves 0.6$1.3 \times 0.3-0.5 \mathrm{~mm}$, weakly concave to almost plane, ovate-lanceolate, longly acuminate, with narrow, straight or recurved apices, looking hyaline when dry; margins entire, occasionally uneven; costa ending at 2/3-3/4 the leaf length; cells of leaf acumen elongate, smooth, uppermost 1-4 apical cells in one row; upper and median laminal cells rounded, $10-15 \mu \mathrm{m}$ in diameter, with thin to moderately thickened walls, weakly collenhymatose, not or slightly bulging in transverse section, with one forked or occasionally simple papillae per cell on both surfaces. Seta smooth, 5-7 mm, reddish brown. Capsule ovate, ca. $1.0 \mathrm{~mm}$ long, symmetric, narrowed to the mouth, light reddish brown, red-brown at mouth, operculum conic, obtuse. Annulus of large cells, falling or persistent. Exostome ca. $200 \mu \mathrm{m}$ long, teeth obtuse at apex, brown and smooth proximally, whitish and papillose distally on outer surface, dorsal trabeculae very low; endostome of basal membrane ca. $1 / 3$ of exostome length, pale brownish, almost smooth, segments rudimentary. Spores 10-12 $\mu \mathrm{m}$, finely papillose. 


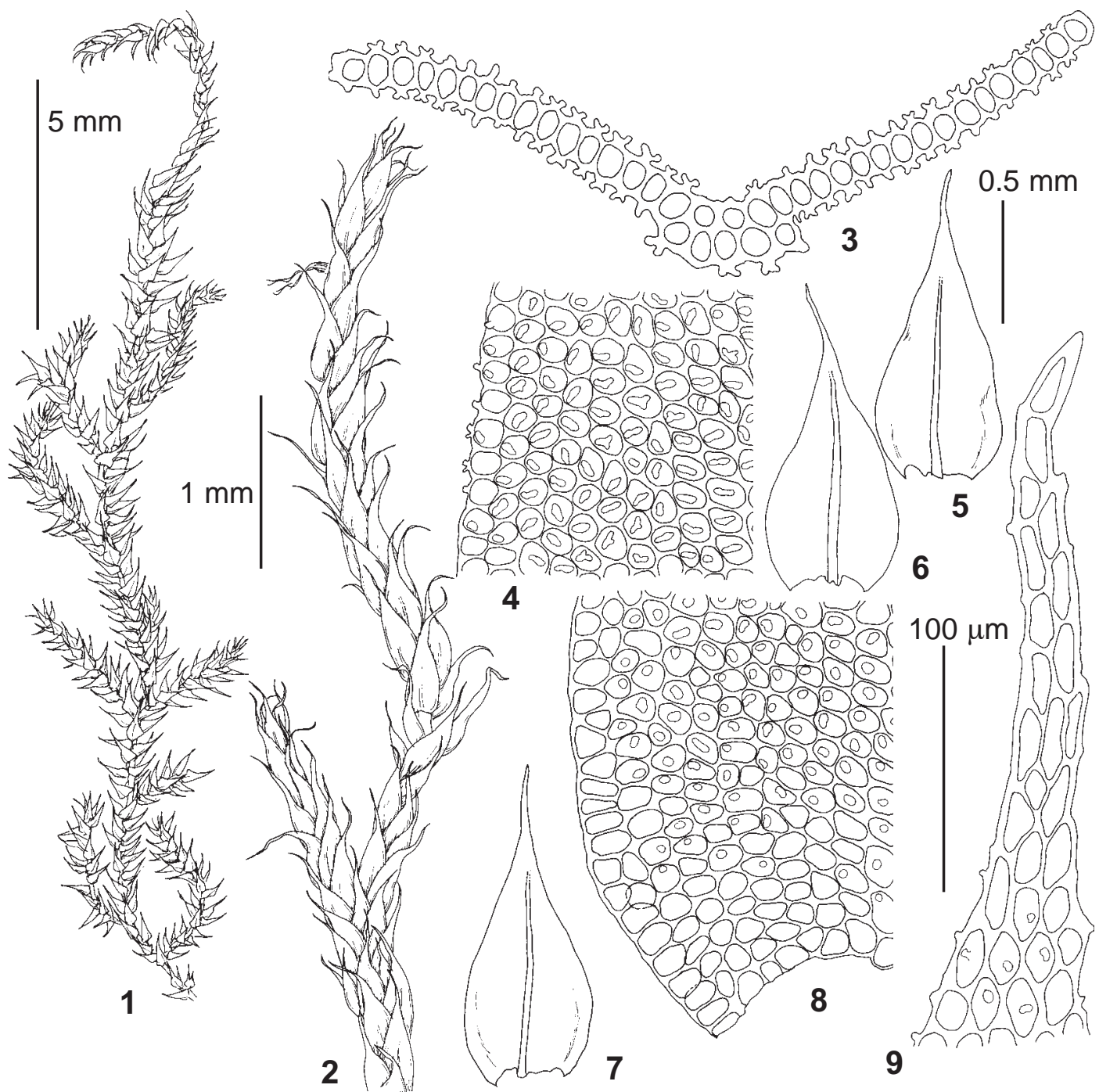

Fig. 2. Lindbergia grandiretis (from Russia, Caucasus, Ignatov \& Ignatova 05-1874): 1 - habit, wet; 2 habit, dry; 3 - leaf transverse section; 4 - median laminal cells; 5-7 - leaves; 8 - basal leaf cells; 9 - upper laminal cells. Scale bars: $5 \mathrm{~mm}$ for $1 ; 1 \mathrm{~mm}$ for $2 ; 0.5 \mathrm{~mm}$ for $5-7 ; 100 \mu \mathrm{m}$ for 3-4, 8-9.

Specimens examined: ARMENIA: Gorissky Distr., Vorotan River Canyon, between Galidzor and Khot, ca. $1000 \mathrm{~m}$ elev., on rotten trunk of Juglans regia, 25.V.1975, Manakyan (LE); RUSSIA: CAUCASUS: Stavropol Territory, Kislovodsk, on Fraxinus, 1915, leg. V.P. Savich, det L.I.Savich (LE); KabardinoBalkaria, Verkhnyaya Balkaria, Ignatov et al. \#051874, 1864 (MHA); Dagestan, Gunib, Ignatov \& Ignatova \#09-496; 674, 642, 645, 368, 371, $716 a$ (MHA); SIBERIA: Buryatia, Bichura River near Bichura settlement $50^{\circ} 31^{\prime} \mathrm{N}, 107^{\circ} 39^{\prime} \mathrm{E}, 753 \mathrm{~m}$ alt., on rocks 6.VII.2007 Afonina \#01607 (LE); Zabaikalsky Territory: Nizhny Tsasuchey, in Ulmis pumila thicket, on Ulmus, 1-1,5 m above ground, common, 1.VII.1988,
Bardunov (LE); Buryat-Agin District, Alhanai Nat. Park 50 56'N, $113^{\circ} 13^{\prime} \mathrm{E}$, on rocks, 9.VII.2006 Afonina \#2206 (LE); Oka Distr., Tsagan-Oluy 12.X.1909, P. Mikhno (LE); Nercha River, Stary Olov, on rocks, 20.VI.1964, Bardunov (LE; KW\#13138);

Both the type of Leskea grandiretis and numerous recent collections from Caucasus have distinct forked papillae (Fig. 2; 4: 5, 7). The latter differentiate it from the North American $L$. brachyptera where papillae are solid, quite massive, often with unclear outlines, as their 'foothills' are quite shallow (Figs. 4: 1-4). The forked papillae in L. grandiretis are best expressed at 


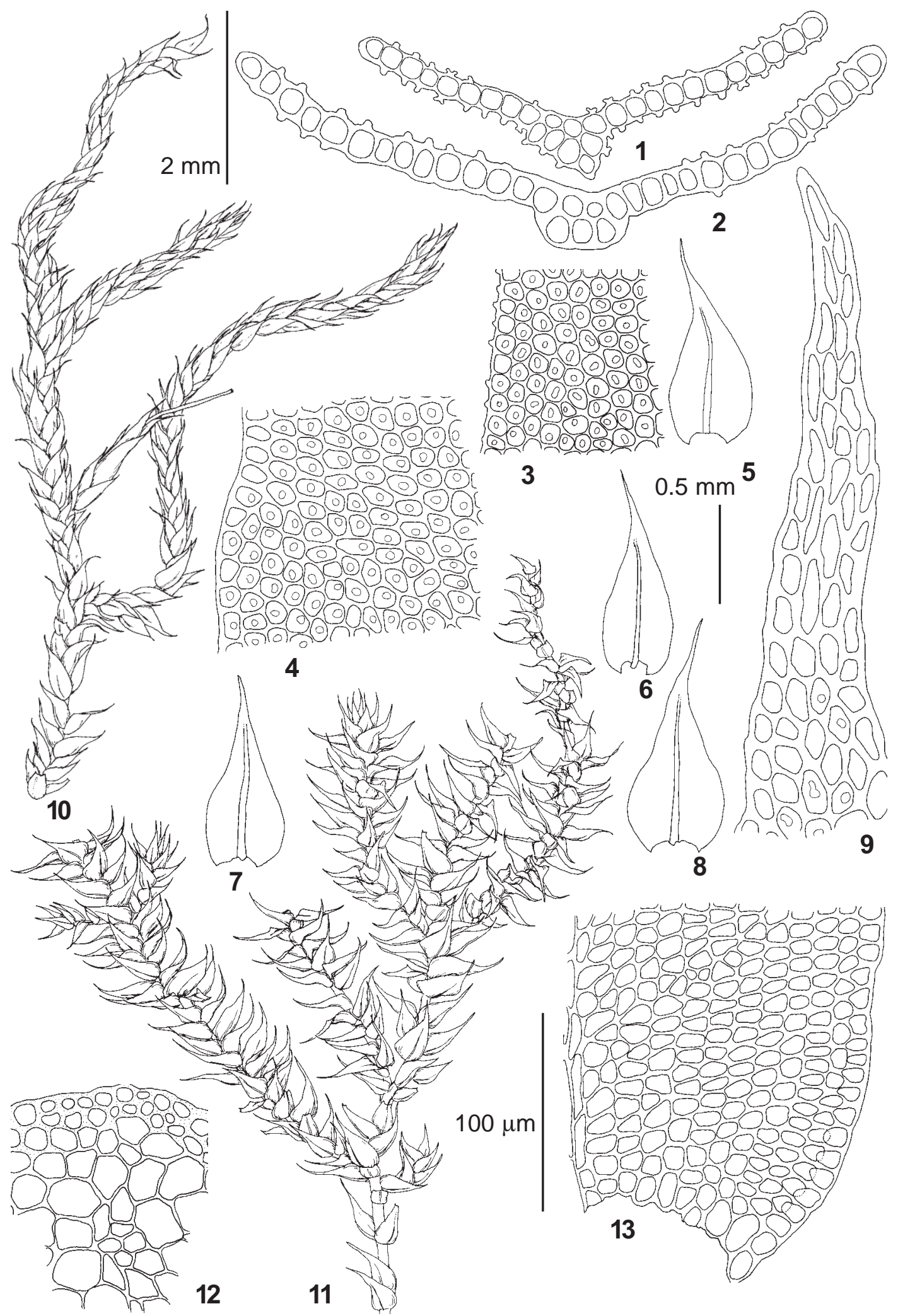


the level of costa end, while below leaf middle they are also massive, sometimes two-toped or just round (Fig. 4: 6). Although in American plants the papillae are reported as 'occasionally bluntly and minutely 2-3 forked' (Crum \& Anderson, 1981), we have seen such papillae very seldom among solid ones, and they always were only quite indistinctly forked.

Siberian plants have papillae somewhat less forked than in Caucasian plants, although in this character they are obviously closer to the latter then to American plants. ITS data fully support this conclusion: five substitutions and one indel differentiate both Caucasian and Transbaikalian specimens from two American ones. Search of L. brachyptera specimens from Japan and China have yielded no one which could be confirmed. Thus we suspect that $L$. brachyptera is a species confined to North America, while in East Asia there is only $L$. grandiretis. A recently described Chinese $L$. brevifolia $\mathrm{C}$. Gao is likely the same, as the main its difference from L. brachyptera is described as forking vs. solid papillae (Cao Tong et al., 2002).

Lindbergia sinensis (Müll. Hal.) Broth., Nat. Pflanzenfam. 1(3): 993. 1907. - Schwetschkea sinensis Müll. Hal., Nuovo Giorn. Bot. Ital., n. ser. 3: 111. 1896.

Figs. 5; 4: 8-9 \& 13; 10

Type: Bryotheca E. Levier, Schwetschkea sinensis C.Müll., Nuovo Giornale botanio italiano 1985 p. 111 c.fr., China interior, provincia Schen-si sept., in medio monte Si-Ki-tzui-sau Jul 1984 legit Rev. Jos. Giraldi determ Prof. C. Müller sub $\mathrm{n}^{\circ}$ 908" (isotype H-BR 2483031!, annotated by Cao Tong).

Lindbergia magniretis (Müll. Hal.) Broth., Nat. Pflanzenfam. 1(3): 993. 1907. - Leskea magniretis Müll. Hal., Nuovo Giorn. Bot. Ital., n. ser. 4: 274. 1897.

Type: Bryotheca E. Levier, Leskea magniretis C. Müll., Nuovo Giornale botanio italiano 1897 p. 274,1898 p. 207 c.fr., China interior, provincia Schen-si sept., Zu-lu(caten. Lao-y-san) 22 Oct. 1896 legit Rev. Jos. Giraldi, determ Prof. C. Müller sub n 2222" (H-BR 2483026!), annotated by Paulo Camara, 2004, Missouri Bot. Garden as isolectotype.
?Lindbergia duthiei (Broth.) Broth., Nat. Pflanzenfam. I(3): 993. 1907. - Leskea duthiei Broth., Acta Soc. Sci. Fenn. 24: 31. 1899.

Lectotype (selected here): "11459 Flora of Kashmir, Leskea Duthie Broth., Sind Valley 67000 ft. 24.6.92, Legit J.F.Duthie" (H-BR 2483024 !). Protologue cited 2 places in Kashmir; both specimens are in $\mathrm{H}-\mathrm{BR}$ and they are subidentical.

Plants dark green or brownish green, in thin mats. Stems 1-3 cm long, irregularly or almost pinnately branching, branches straight or arcuate, 2-5 mm long. Stem and branch leaves 0.9$1.3 \times 0.4-0.7 \mathrm{~mm}$, weakly concave to almost plane, ovate-lanceolate, shortly to longly acuminate, with straight or recurved apices when dry; margins entire, occasionally uneven; costa ending at 2/3-3/4 the leaf length; cells of leaf acumen elongate; upper and median laminal cells rounded, 10-12×10-14 $\mu \mathrm{m}$, firm-walled, weakly collenhymatose, not bulging in transverse section, smooth or with one very small, hardly visible simple papilla per cell on dorsal or both surfaces. Seta smooth, 5-7 mm, reddish. Capsule ovate, 1.0-1.1 $\mathrm{mm}$ long, symmetric, narrowed to the mouth, redbrown, operculum conic, with short obtuse beak. Annulus absent. Exostome ca. $220 \mu \mathrm{m}$ long, teeth obtuse at apex, whitish, finely papillose on outer surface, dorsal trabeculae moderately high; endostome of basal membrane ca. 1/4 of exostome length, white, finely papillose, segments absent. Spores 20-25 $\mu \mathrm{m}$, reddish brown, finely papillose.

Specimens examined: RUSSIA: Primorsky Territory: Nakhodka, Sestra Mt., Ignatov 08-257 (MHA); Khanka Distr., Melgunovka River, Ignatov 08-370 (MHA); Vladivostok, Bolshaya Sedanka, Ignatov et al., 06-2476 (MHA); Khabarovsk, Ignatov 97-567 (MHA); Vladivostok, between Okeanskaya and Sanatornaya, Gorobets \#542 (MHA); Vladivostok, Gorobets \#60 (MHA); Lazo Distr., Kamenka 24.IX.1974 Bardunov \& Cherdantseva (IRK, as L. duthie); Lazo Distr., Kievka Gorobets \#84 (MHA); Lazovsky Distr., Kamenka 24.9.1974 Bardunov \& Cherdantseva (MHA); Vladivostok, Okeanskaya, in forest above the line of frequent fog, on oak trunk, 30.IX.1933, Lazarenko (LE); Vladivostok surroundings, Bogataya Gri-

Fig. 3. Lindbergia grandiretis (from Russia, Zabaikalsky Territory, Nizhnij Tsasuchey, 1.VII.1988, Bardunov, LE): 1-2 - leaf transverse sections; 3-4 - median laminal cells; 5-8 - leaves; 9 - upper laminal cells; 10 - habit, dry; 11 - habit, wet; 12 - stem transverse section; 13 - basal leaf cells. Scale bars: $2 \mathrm{~mm}$ for 10-11; $0.5 \mathrm{~mm}$ for $5-8 ; 100 \mu \mathrm{m}$ for $1-4,9,12-13$. 

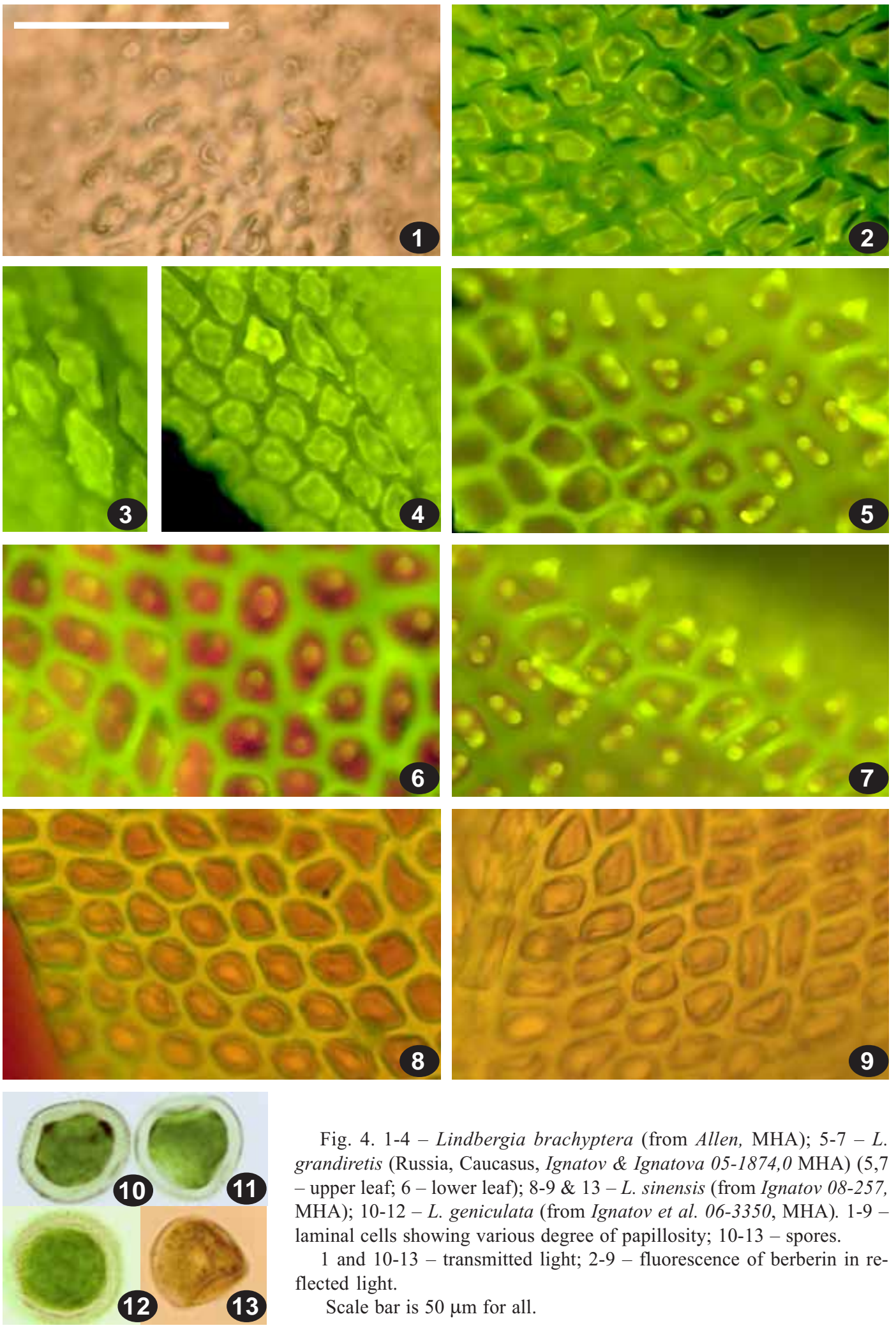

Fig. 4. 1-4 - Lindbergia brachyptera (from Allen, MHA); 5-7 - L. grandiretis (Russia, Caucasus, Ignatov \& Ignatova 05-1874,0 MHA) (5,7 - upper leaf; 6 - lower leaf); 8-9 \& 13 - L. sinensis (from Ignatov 08-257, MHA); 10-12 - L. geniculata (from Ignatov et al. 06-3350, MHA). 1-9 laminal cells showing various degree of papillosity; 10-13 - spores.

1 and 10-13 - transmitted light; 2-9 - fluorescence of berberin in reflected light.

Scale bar is $50 \mu \mathrm{m}$ for all. 
va, on Quercus mongolica trunk, 30.IX.1933, Lazarenko (LE); Khabarovsk Territory (now Primorsky Territory), Bikin Distr., Krasnyj Pereval on Bikin River; on rocks. 2.X.1935, A.S. Lazarenko (KW13139, as L. japonica).

A revision of specimens from Primorsky and Khabarovk Territories, including those reported as Lindbergia japonica by Lazarenko (1941) and as L. duthiei by Bardunov (1982), shows their identity with the widespread East Asiatic species L. sinensis.

Material of $L$. duthiei studied in H-BR does not show any substantial difference from $L$. sinensis, except for slightly larger plants. They quite likely belong to the same species, which is however better to proof genetically before their formal synonymization.

\section{Note on Lindbergia japonica}

Lindbergia sinensis differs from L. japonica (as described by Noguchi, 1972) mainly in rather uniform ovate to ovate-lanceolate, acuminate leaves (usually 1-1.3 mm long) and more or less frequent sporophyte production. Contrary to this, Lindbergia japonica has small leaves (0.5-0.9 $\mathrm{mm}$ long) and has never been reported with sporophytes. Leaf descriptions are strongly incongruent between authors: in the original description Cardot mentioned shortly acuminate leaves with costa less prominent comparatively with $L$. magniretis (synonymized with $L$. sinensis), whereas the illustration of Noguchi (1.c.) shows longly aciminate leaf with percurrent costa.

We studied putative isotypes of Lindbergia japonica in $\mathrm{H}$ and $\mathrm{S}$, both being very scanty in material ["Herb. J. Cardot Lindbergia japonica Card. sp. nova, Japon: rocher de Zarnishi, Leg. Faurie, 1908, n. 3885" (H-BR 2483030!), same in S!]. Plants from these specimens are very variable, having stem leaves rather short acuminate, but branch leaves being lanceolate. The most important, however, is the fact that the leaf cells were not described by Cardot as papillose (implying that they are smooth?), but Noguchi described them as having one large papilla over the lumen. However, we found cells to be smooth in both isotypes we studied and have no explanation to this disagreement. Also, although plants of these isotypes have much in common with Lindbergia sinensis and Mamillariella geniculata in habit, their basal juxtacostal cells are somewhat elongate, which disagrees with Lindbergia.

The further studies on identity of L. japonica should be done, but regardless to it, the specimen named as L. japonica and reported by Lazarenko from the Russian Far East in KW belongs to L. sinensis.

\section{Notes on papillae in Lindbergia sinensis}

Small papillae on laminal cells were not found in lectotype of Lindbergia sinensis, but they were observed in isolectotype in S. The presence and expression of papillae in this group need a comment.

The papillae in L. sinensis is not a very definite character: in some specimens low papillae occur in some leaves, while in others no traces of them can be discerned. In some collections we were able to find a leaf with papillae after checking many leaves, choosing the best developed ones. The expanded search, however, cannot be applied to scanty specimens of original collections. Likely because of this indefinite situation, papillae were almost never discussed in this group. Nothing is said about papillae in the original description of Schwetschkea sinensis, while Cao Tong et al. (2002) key out this species as smooth-celled.

This is true in general, but at places small papillae are observed in limited areas, being at best very low (Figs. 4: 8-9, 5: 4), like in a least expressed cases of L. brachyptera (Fig. 4: 1-4). In exceptional cases they are more apparent, and it is better to keep this in mind to avoid misinterpretation.

Lindbergia geniculata (Laz.) Ignatova \& Ignatov comb. nov. - Mamillariella geniculata Laz., Izv. Kievsk. Bot. Sada 18: 104. 1-5. 1934.

Figs. 6; 4: 10-12; 9

Holotype: "ДСК, Приморська обл., Посьетский р-н, бухта Сідімі, парк, на деревах 28.X.1933 А.Лазаренко" [Far East Territory. Posiet Distr., Sidimi Bay, park, on trees, 28.X.1933 A.Lazarenko] (KW 13145).

Plants yellowish green or brownish green, in thin mats. Stems 1-2 cm long, irregularly or subpinnately branching, branches straight or arcuate, 2-4 mm long. Stem and branch leaves 0.6$0.9 \times 0.3-0.4 \mathrm{~mm}$, weakly concave to almost plane, ovate-lanceolate, acute or shortly to longly acumi- 


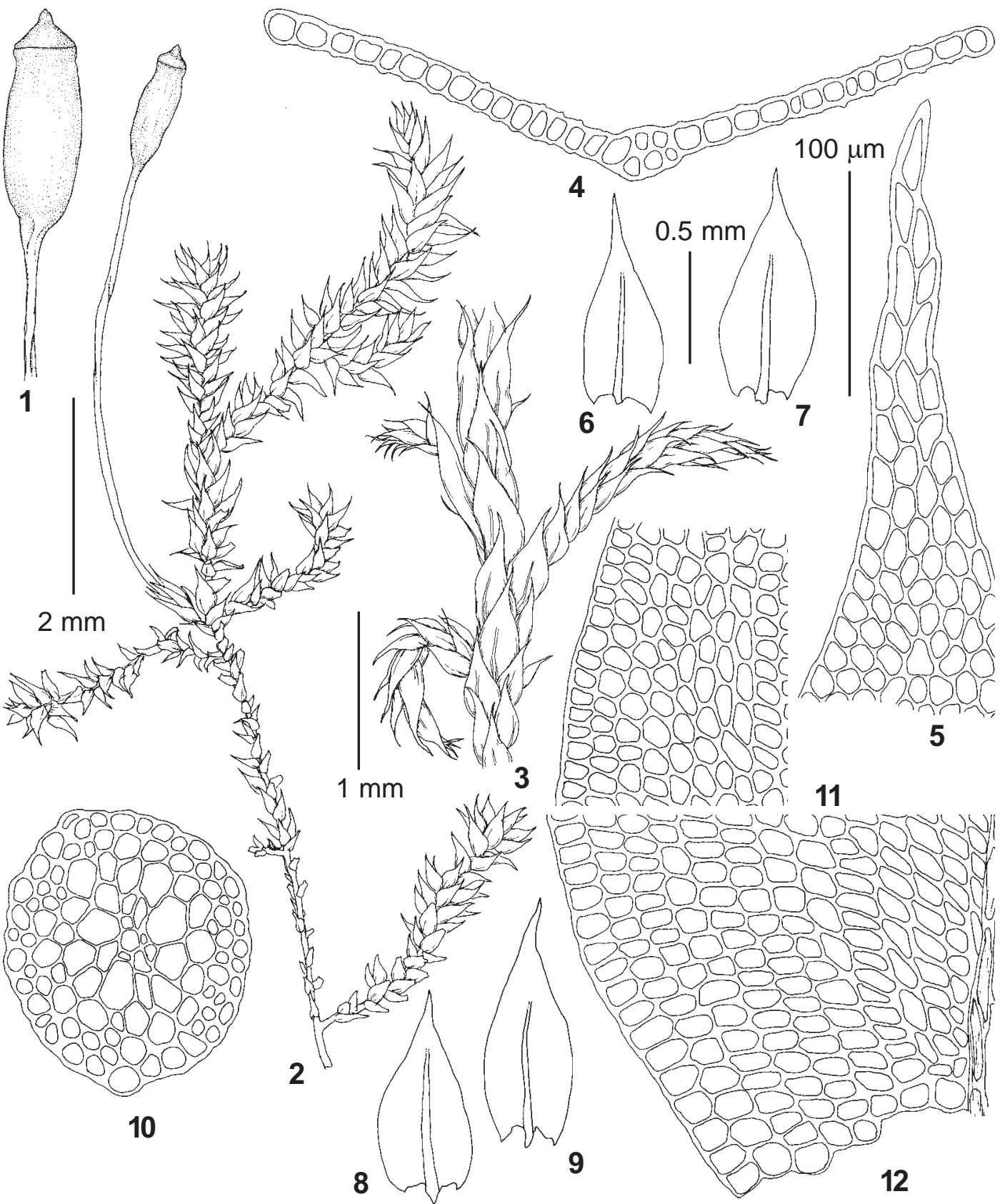

Fig. 5. Lindbergia sinensis (Müll. Hal.) Broth. (from Primorsky Territory, Lazo Distr., Kamenka 24.IX.1974 Bardunov \& Cherdantseva (IRK, as L. duthiei): 1 - capsule; 2 - habit, wet; 3 - habit, dry; 4 - leaf transverse section; 5 - upper laminal cells; 6-9 - leaves; 10 - stem transverse section; 11 - median laminal cells; 12 basal cells. Scale bars: $2 \mathrm{~mm}$ for $2 ; 1 \mathrm{~mm}$ for 1,$3 ; 0.5 \mathrm{~mm}$ for $6-9 ; 100 \mu \mathrm{m}$ for $4-5,10-12$.

nate, mostly with straight apices when dry; margins entire, occasionally uneven; costa ending at 2/3-3/4 the leaf length; cells of leaf apex isodiametric, occasionally several uppermost cells in one row; upper and median laminal cells rounded or ovate, $8-10 \times 10-15 \mu \mathrm{m}$, thick-walled, collenhymatose, not bulging in transverse section, smooth. Seta finely mamillose, 4-6 mm, yellow-green proximally, pale brownish distally. Capsule ovate, 1.0$1.3 \mathrm{~mm}$ long, symmetric, narrowed to the mouth, 


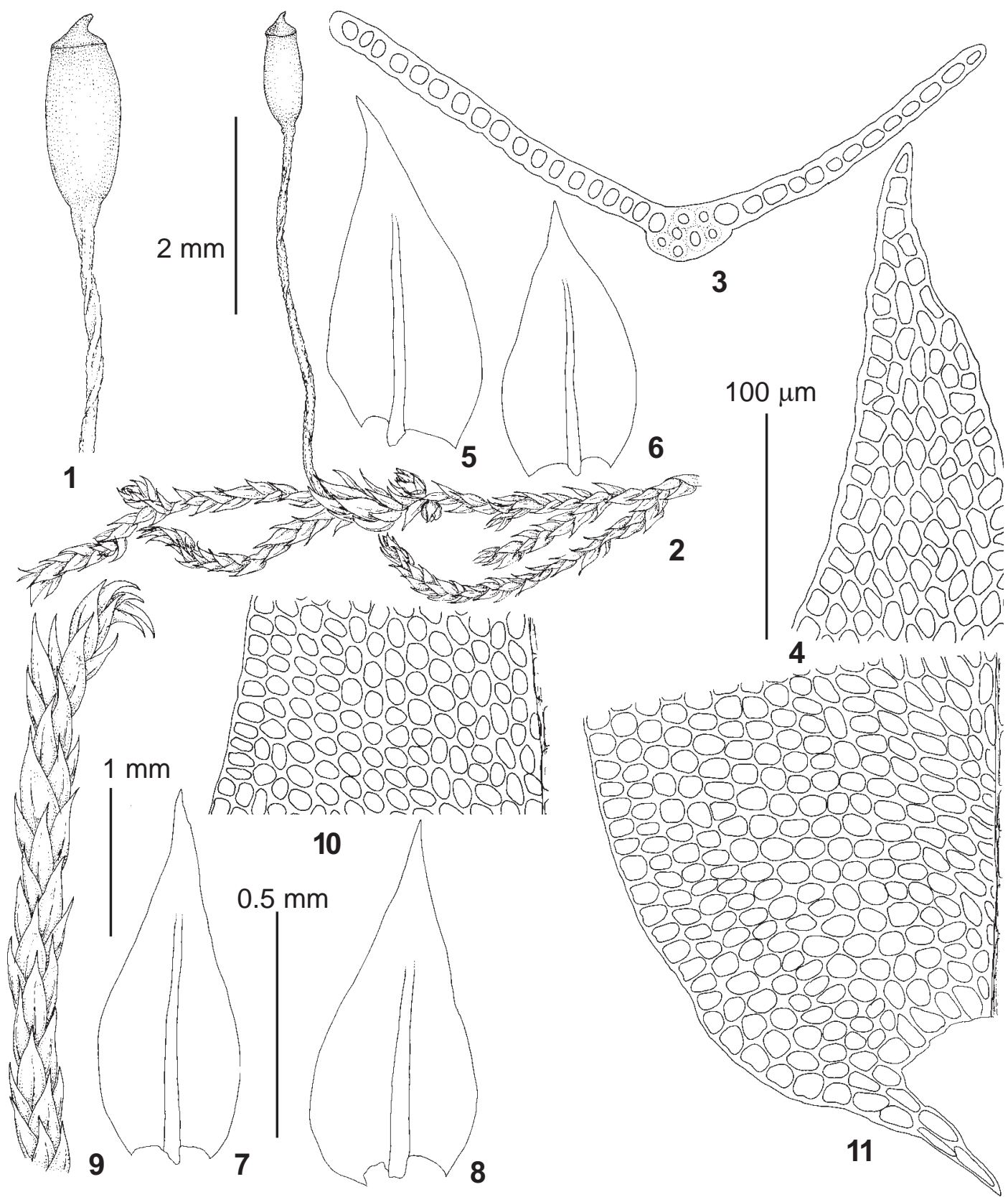

Fig. 6. Lindbergia geniculata (from Russia, Primorsky Territory, Ignatov 08-383, MHA): 1 - capsule; 2, 9 habit, dry; 3 - leaf transverse section; 4 - upper laminal cells; 5-8 - leaves; 10 - median laminal cells; 11 basal cells. Scale bars: $2 \mathrm{~mm}$ for $2 ; 1 \mathrm{~mm}$ for 1,$9 ; 0.5 \mathrm{~mm}$ for $5-8 ; 100 \mu \mathrm{m}$ for 3-4, 10-11.

red-brown, operculum conic, with short straight or oblique beak. Annulus absent. Exostome ca. 200 $\mu \mathrm{m}$ long, teeth whitish, smooth distally, papillose proximally on outer surface, dorsal trabeculae moderately high, papillose; endostome absent. Spores 25-30 $\mu \mathrm{m}$, finely papillose.
Specimens examined: RUSSIA: Primorsky Territory: same loc. as type (KW 13143): Okeanskaya, 30.IX. 1933, Lazarenko (KW 13142; 13146); Upper Suputinka, 11.IX.1934, Lazarenko (KW 13141); Tumannaya Peak, 2.IX.1936, Kolesnikov (KW 13140); Sichote-Alin, Fl. Volcha infer., 13.VII.1927, V.A.Petrov (KW 13144); Bolshaya Sedanka, Ignatov et al. 06- 
3350 (MHA); Khasan Distr., Andreevka, 21.VII.1988, Mikulin (MHA ex VLA); Partizansky Distr., Lozovyj Range, 15.IX.1974, Bardunov \& Cherdantseva (MHA ex VLA).

The broad generic concept urges to consider the genus Mamillariella within Lindbergia. By hametophytes $L$. geniculata is difficult to separate from L. sinensis, although their confusion is unlikely, since both commonly occur with sporophytes that have many differencies. The most peculiar is the seta, which is mamillose, the mamillae varying from high and acute to rather moderate.

Two other important characters are almost complete reduction of endostome (L. sinensis has a rather high basal membrane), and very thickwalled spores (Fig. 4: 10-13).

Lindbergia dagestanica Ignatova \& Ignatov sp. nov.

Figs. 7; 11: 1-5

Species L. mexicana affinis sed dentes exostomii externi laevibus.

Holotypus: Dagestan, on bark of tree near waterfalls on summit of mountain opposite Gunib. 5.IX.1932. Samsel \#119 (MW).

Plants yellowish-green, olivaceous or brownish, in thin mats. Stems to $1-3 \mathrm{~cm}$ long, irregularly branching, branches straight or arcuate, 3-6 mm long. Stem and branch leaves 0.7-0.9×0.5-0.6 mm, weakly concave to almost plane, broadly ovate, shortly acuminate, with straight apices when dry; margins entire or weakly serrulate, occasionally slightly wavy; costa ending few cells below the apex; upper and median laminal cells rombic to short rectangular, 10-15×6-9 $\mu \mathrm{m}$, with moderately thickened walls, weakly collenhymatose, not bulging in transverse section, smooth. Seta smooth, 7-8 mm, reddish brown. Capsule ovate, 1.8-2.1 $\mathrm{mm}$ long, symmetric or slightly asymmetric, erect, constricted below the mouth when dry, light reddish brown, red-brown at mouth; operculum and annulus not seen. Exostome ca. $230 \mu \mathrm{m}$ long, teeth narrow, yellowish, smooth on outer surface, dorsal and ventral trabeculae very low; endostome pale yellowish, basal membrane ca. 1/4 of exostome length, finely and distantly papillose, segments narrow, not keeled, to $1 / 2$ the exostome length. Spores $15-20 \mu \mathrm{m}$, finely papillose.

The species known only from the holotype. An inegmatic plant from Dagestan that initi- ated this studiy was first found to be very similar to L. mexicana (Besch.) Cardot. Overall habit, leaf shape, areolation and cylindric capsule strongly contracted below mouth clearly indicated their close affinity. As fresh collections of Dagestan plant were not available, sequences were studied only for Bolivian plant of $L$. mexicana and two specimens of L. patentifolia Dixon from South Africa. Surprisingly, ITS sequences of Bolivian and South African plants were found to be almost identical (mutations in ITS between Bolivian and South African specimens are at the same level as between two specimens from South Africa).

These two species have much in common, but leaves in L. mexicana are ovate, while in L. patentifolia ovate-lanceolate. More expanded analysis is needed to find out if this character is stable enough, but preliminary study indicates no reason to lump these species.

This group of the genus Lindbergia is represented by one species in America, from southern United States to Andes in South America, and in South Africa where it is far more diverse. Lindbergia patentifolia seems the most similar to $L$. mexicana; L. haplocladioides Dixon (isotype in H-BR 2482015!) has narrow leaves, often homomallous; L. abbreviata Broth. has recurved leaf tip and is habitually not similar; L. pseudoleskeelloides Dixon has dull cells; while L. viridis Dixon differs from L. mexicana and other species of the group in somewhat narrower leaves and smaller plants.

Caucasian plants have almost no differences from L. mexicana in gametophyte, while the peristome characters are not identical. Plants from Bolivia (Fig. 12) have distinctly papillose outer exostome surface that has prominent joinings between plates, and endostome membrane is also slighlty papillose. Contrary to this, L. dagestanica has smooth teeth and basal membrane, and in addition even in old capsule the segment fragments are retained (Fig. 11: 1, 5), while both our observations and literature data agree in absence of segments in L. mexicana.

Lindbergia patentifolia in respect to peristome papillosity is similar to L. mexicana (Fig. 11: 67), although a certain caution is needed, as the species was described from Uganda by sterile 


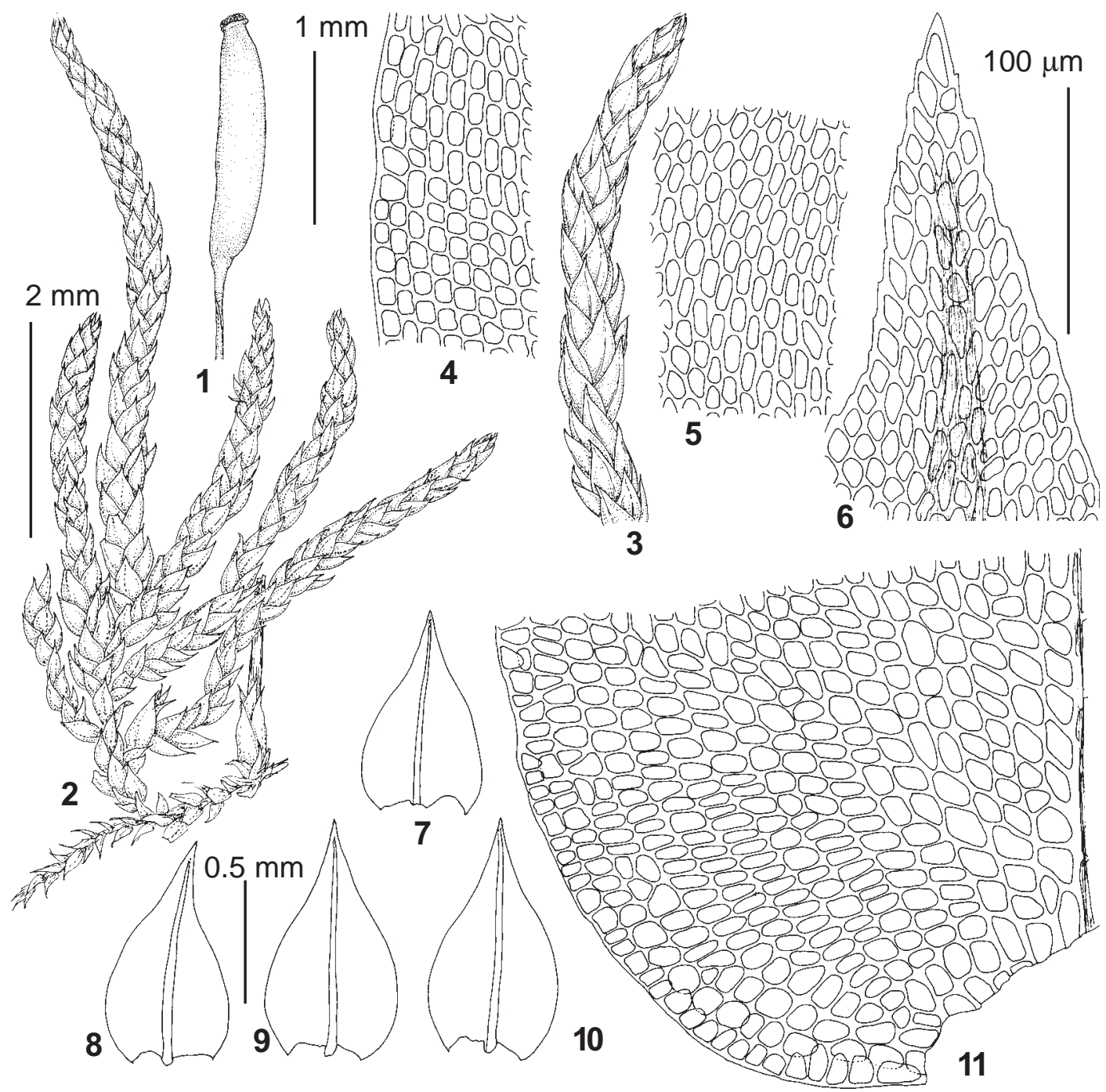

Fig. 7. Lindbergia dagestanica sp. nov. (from holotype: Russia, Dagestan, Gunib, 5.IX.1932. Samsel \#119, MW): 1 - capsule; 2,3 - habit, dry; 4-5 - median laminal cells; 6 - upper laminal cells; 7-10 - leaves; 12 - basal cells. Scale bars: $2 \mathrm{~mm}$ for $2 ; 1 \mathrm{~mm}$ for 1,$3 ; 0.5 \mathrm{~mm}$ for $6-9 ; 100 \mu \mathrm{m}$ for $4-5,10-12$.

plants (Dixon, 1918). Subsequently Sims (1926) provided an expanded description of peristome, with teeth being finely striolate, terminal joints papillose; membrane nearly half as high as peristome [although in illustrations $1 / 3-1 / 4$ high], firm, densely papillose, without processings and ciliae. Seemingly, this observation had been done on South African material. Our SEM micrographs (done from one of specimens used for DNA study brought the same results. And in addition the studied plants from Ethiopia (ex Dixon Herb. 2100 m Piovano 13.X.1937, MHA) also have papillose exostome.
Thus the collection from Dagestan appears to be different in peristome structure, which is (1) completely smooth on abaxial surface and with only very slightly exserted dorsal trabeculae vs. papillose, especially along more or less exserted dorsal trabeculae; (2) has smooth basal membrane of endostome vs. papillose; (3) has segments, although narrow and fragile, but nevertheless clearly seen at least in several places even in old capsules. These differences forced us to describe Caucasian plants as a separate new species, Lindbergia dagestanica. 


\section{KEY TO IDENTIFICATION \\ OF LINDBERGIA SPECIES IN RUSSIA}

1. Leaf lamina distinctly papillose; papillae mostly forked L. grandirete

- Leaf lamina smooth or with few very small, hardly visible papillae 2

2. Leaves broadly ovate, short acuminate; upper and median leaf cells rombic to short rectangular; costa ending few cells below leaf apex; capsule ca. $2 \mathrm{~mm}$ long, cylindrical, constricted below the mouth; endostome with narrow segments; Caucasus, very rare

L. dagestanica

- Leaves broadly ovate-lanceolate, short to long acuminate; upper and median leaf cells rounded or ovate; costa reaching 2/3-3/4 the leaf length; capsule ca. $1 \mathrm{~mm}$ long, ellipsoidal, not constricted below the mouth; endostome consists of basal membrane only or absent; Russian Far East, sporadic 3

3. Setae smooth; endostome present; cells of attenuate leaf apices elongate; spores 20-25 $\mu \mathrm{m}$ L. sinensis

- Setae mamillose; endostome absent; cells of attenuate leaf apices short; spores 25-30 $\mu \mathrm{m}$ L. geniculata

\section{ACKNOWLEDGEMENTS}

We are indebted to curators of $\mathrm{S}$ and $\mathrm{H}$ for providing specimens for our study, to Vladimir Fedosov for the help with SEM studies, and to Vladimir P. Prokhorov for the Latin diagnosis. The work of was partially supported by RFBR grants 10-04-00678 \& 10-04-91150 and Biodiversity Program of RAS.

\section{LITERATURE CITED}

ARIKAWA, T. 2004. A taxonomic study of the genus Pylaisia (Hypnaceae, Musci). - J. Hattori Bot. Lab. 95: 71-154.

[BARDUNOV, L.V.] БАРДУНОВ Л.В. 1969. Определитель листостебельных мхов Центральной Сибири. - [Handbook of mosses of the Central Siberia] Л., Наука [Leningrad, Nauka], 329 pp.

[BARDUNOV, L.V. \& V.Ya.CHERDANTSEVA] БАРДУНОВ Л.В., В.Я.ЧЕРДАНЦЕВА 1982. Листостебельные мхи Южного Приморья. - [Mosses of the South of Primorsky Territory] Новосибирск, Наука [Novosibirsk, Nauka], 208 pp.

BROTHERUS, V.F. 1892. Enumeratio muscorum Caucasi. Acta Soc. Sci. Fenn. 19(12): 1-170.

BROTHERUS, V. F. 1898[1899]. Contributions to the bryological flora of the N. W. Himalaya. -Acta Soc. Sci. Fenn. 24: $1-46$.
BROTHERUS, V. F. 1925. Musci. 2. - In: Engler, A. \& K. Prantl, (eds.), Die Natürlichen Pflanzenfamilien, ed. 2, W. Engelmann, Leipzig: 1-522.

BUCK, W. R. 1980. A re-interpretation of the Fabroniaceae: additions and corrections. - J. Hattori Bot. Lab. 47: 45-55.

CAO TONG, SUN JUN \& GAO CHIEN 2002. Leskeaceae.In: Moss Flora of China, English Version, Vol. 6, Beijing, ew York and St.-Louis, Science Press and Missouri Botanical Garden: 99-130.

COX, C. J., B. GOFFINET, N.J.WICKETT, S.B. DOLES \& A.J.SHAW 2010. Moss diversity: a molecular phylogenetic analysis of genera. - Phytotaxa 9: 175-195.

CRUM, H.A. \& L.E. ANDERSON 1981. Mosses of Eastern North America (Vol. 1-2). - New York, Colombia University Press, $1328 \mathrm{pp}$

DU, GUI-SEN \& HUI ZHANG 2005 Molecular phylogeny of Thuidiaceae (Musci) and related taxa inferred from rDNA ITS sequence. - International Bryological Symposium for Prof. Pan-Chieh Chen's Centennial Birthday [Abstracts]. Chinese Botanical Society: Nanjing. 40.

DIXON, H. N. 1918. Uganda mosses collected by R. Duemmer and others. - Smithsonian Misc. Collect. 69(8): 1-10.

GARCI'A-AVILA, D. E. DE LUNA \& A. E. NEWTON 2009. Phylogenetic relationships of the Thuidiaceae and the nonmonophyly of the Thuidiaceae and the Leskeaceae based on rbcL, rps4 and the rsp4-trnS intergenic spacer. - Bryologist 112: $80-93$.

GARDiner, A., M. IGNATOV, S. HUTtUNEN \& A. TROITSKY 2005. On resurrection of the families Pseudoleskeaceae Schimp. and Pylaisiaceae Schimp. (Musci, Hypnales). - Taxon 54: 651-663.

GOFFINET, B., W. R. BUCK \& A. J. SHAW 2009 [2008].Morphology, anatomy, and classification of the Bryophyta. - In: Goffinet, B. \& A. J. Shaw (eds.) Bryophyte Biology, $2 d$ ed. Cambridge University Press: Cambridge: 55-138.

GOLOBOFF, P. A. 1994. NONA: A Tree Searching Program. - Program and documentation. Argentina, Tucumбn, published by the author.

HUTTUNEN, S., L. HEDENÄS, M. IGNATOV, N. DEVOS \& A. VANDERPOORTEN 2008. Origin and evolution of the Northern Hemisphere disjunctions in the moss genus Homalothecium (Brachytheciaceae). - Am. J. Bot. 95: 720-730.

IGNATOV, M.S., O.M. AFONINA, E.A. IGNATOVA et al. 2006. Check-list of mosses of East Europe and North Asia. Arctoa 15: 1-130.

IGNATOV M.S., V.E. FEDOSOV, E.A. IGNATOVA, G.YA. DOROSHINA \& V.I. ZOLOTOV 2010. Moss flora of Gunib area in Dagestan, Caucasus. - Arctoa 19: 87-96.

IGNATOV, M., A. GARDINER, V. BOBROVA, I. MILYUTINA, S. HUTTUNEN \& A. TROITSKY 2007. On the relationships of mosses of the order Hypnales, with special reference to taxa traditionally classified in the Leskeaceae. - In: Newton, A.E. \& R. Tangney (eds.), Pleurocarpous mosses: systematics and evolution. CRC Press, Bocan Rota-London-New York: 177-213.

[LAZARENKO, A.S.] ЛАЗАРЕНКО А.С. 1934. Mamillariella geniculata Lazar. - новий рід листяного моху 3 
Південно-Уссурійського краю. - [Mamillariella geniculata Lazar. - a new moss genus from the South Ussuri Region] Вісн. Киівськ. Бот. Саду [Visnik Kievsk. Bot. Sadu] 18: 103-107.

[LAZARENKO, A.S.] ЛАЗАРЕНКО А.С. 1941. Листяні мохи Радянського Далекого Сходу. 2. Acrocarpae: OrthotrichalesEubryales; Pleurocarpae: Isobryales-Hypnobryales (Theliaceae-Leskeaceae). - [Mosses of the Soviet Far East. 2. Acrocarpae: Orthotrichales-Eubryales; Pleurocarpae: Isobryales Hypnobryales (Theliaceae-Leskeaceae)]. Бот. Журн. АH YPCP [Bot. Zhurn. Akad. Nauk Ukr. RSR] 2(1): 51-95.

LEVIER, E. 1906. Muscenee raccolte nello Schen-si(Cina) dal Rev. Guseppe Giraldi. - Nuovo Giorn. Bot. Ital., n.s. 13: 237-280.
NIXON, K.C. 1999. Winclada (BETA) ver. 0.9.9. available at http://www.cladistics.com/about_winc.html.

NOGUCHI, A. 1972. Musci Japonici. IX. The Leskeaceae. - J. Hattori Bot. Lab. 36: 499-529.

QUANDT, D. \& M. STECH 2005. Molecular evolution and secondary structure of the chloroplast trnL intron in bryophytes. - Molec. Phylog. Evol. 36: 429-443.

SIMS, T.R. 1926. The bryophyta of South Africa. - Trans. Royal Soc. South Africa 15: $475 \mathrm{pp}$.

WIJK, R.. VAN DER, W.D. MARGADANT \& P.A. FLORSCHUTZ 1964. Index muscorum. Vol. 3. - Regnum Veget. 33, $529 \mathrm{pp}$.

Appendix 1. Taxon sampling and Genbank accession numbers.

Species

GenBank

ITS1

ITS2

trnL-F

AY009802 AY009802

AJ417494 AJ417494

A. abietina (Hedw.) M. Fleisch. 2

Actinothuidium hookeri (Mitt.) Broth.

Amblystegium serpens (Hedw.) Bruch \& al.

Anomodon longifolius (Brid.) Hartm.

A. rugelii (Müll. Hal.) Keissl.1

Anomodon rugelii (Müll. Hal.) Keissl.2

Boulaya mittenii (Broth.) Cardot

Campylophyllum halleri (Hedw.) M. Fleisch.

Claopodium crispifolium (Hook.) Ren. \& Cardot

Climacium americanum Brid.

Cratoneuron filicinum (Hedw.) Spruce

Haplocladium angustifolium (Hampe \& Müll. Hal.) Broth.

Helodium blandowii (F. Weber \& D. Mohr) Warnst.

Hygrohypnum luridum (Hedw.) Jenn.

Hylocomium splendens (Hedw.) Bruch et al.

Isopterygiopsis muelleriana (Schimp.) Z. Iwats.

Lescuraea plicata (Schleich. ex F. Weber \& D. Mohr) Schimp.

L. saxicola (Bruch \& al.) Mol.

Leskea gracilescens Hedw.

L. polycarpa Hedw. 1

L. polycarpa Hedw. 2

Lindbergia brachyptera (Mitt.) Kindb.1 (USA, Churchill 1328, H)

L. brachyptera (Mitt.) Kindb.2 (USA: H: H3194519)

L. geniculata (Laz.) Ignatova \& Ignatov (Primorsky Territory, 21.VII.1988 Cherdantseva s. n., MHA)

L. grandiretis (Lindb. ex Broth.) Ignatov \& Ignatova 1

(Dagestan, Ignatov \& Ignatova 09-496, MHA)

L. grandiretis (Lindb. ex Broth.) Ignatov \& Ignatova 2

(Zabaikalsky Territory, 1.VII.1988 Bardunov, MHA)

L. mexicana (Besch.) Cardot (Bolivia, Churchill 24643, MHA)

L. patentifolia Dixon 1 (South Africa, Rooy 9771800, H)

L. patentifolia Dixon 2 (South Africa, Phephu 28, H)

L. sinensis (Müll. Hal.) Broth. 1 (Primorsky Territory, Ignatov 97-567, MHA)

L. sinensis (Müll. Hal.) Broth. 2 (Primorsky Territory, Ignatov \& al. 06-2476, MHA) J

Loeskeobryum brevirostre (Brid.) M. Fleisch.

Ochyraea smithii (Sw.) Ignatov \& Ignatova

Ochyraea tatrensis Váňa

Pseudoleskeella catenulata (Brid. ex Schrad.) Kindb.
AY568547 AY568547

AF168152 AF168152

AY695750 AY695766

AJ288420 AJ277232

FM161080 FM161080

AY683610 AY693655

AY695739 AY695778

AY009812

AY009812

AY528884 AY528885

AY009803

AF168137

AY009803

AF168137

AJ288336

AY528882

AJ270021

AY695740

AY528882

AF516165

AY695765

AY695774

AF176277

AF176277

AY528889

AF516151

AY568554

AY568554

AY695760 AY695763

FM161151

FM161151

AY693652

AY693652

JF280965 JF280965

JF280966

JF280967

JF280968

JF280969

AF516170

JF280966

JF280967

JF280968

JF280969

AF516153

JF280970

JF280975

AJ270022

AF168139

AF168139

AF260916

AY695747

AF516154
AY683597

AY009827

AY683562

AF161116

AM990347

AY693655

AY683583

AF161158

AY009817

AY527129

AY009852

AY009862

AF152385

AY527138

AY 683596

AY683569

AY527134

AY683571

AM990407

JF280979

JF280980

AY683572

AF161172

AY009856

AF260915

AY683578 

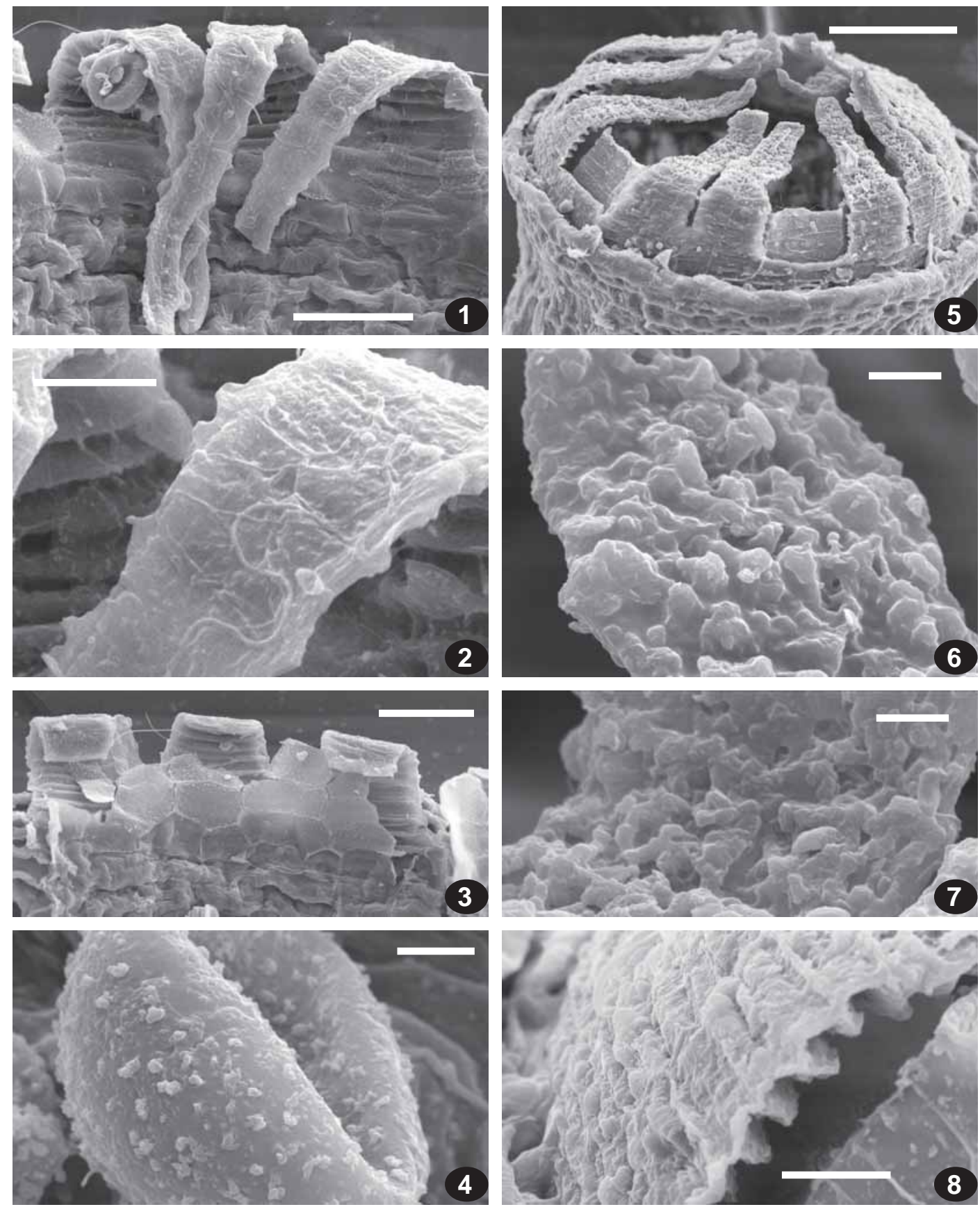

Fig. 8. 1-4: Lindbergia brachyptera (from USA, Allen, MHA) and 5-9: L. grandiretis (from Russia, Dagestan, Ignatov \& Ignatova 09-645, MHA): 1 \& 5 peristomes; $2 \& 6$ - outer surface in distal teeth; 3 part of peristome from inside, showing exostome represented by basal membrane; 4 - spore; 7 - outer surface of tooth in the middle; 8 - outer surface of tooth at base; 9 - spore surface. Scale bars: $1,3-50 \mu \mathrm{m} ; 2,8-$ $15 \mu \mathrm{m} .4,6-7-5 \mu \mathrm{m} ; 5$ - $100 \mu \mathrm{m} ; 9-3 \mu \mathrm{m}$

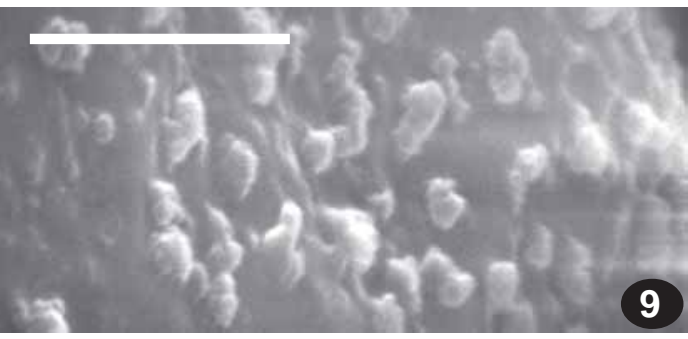



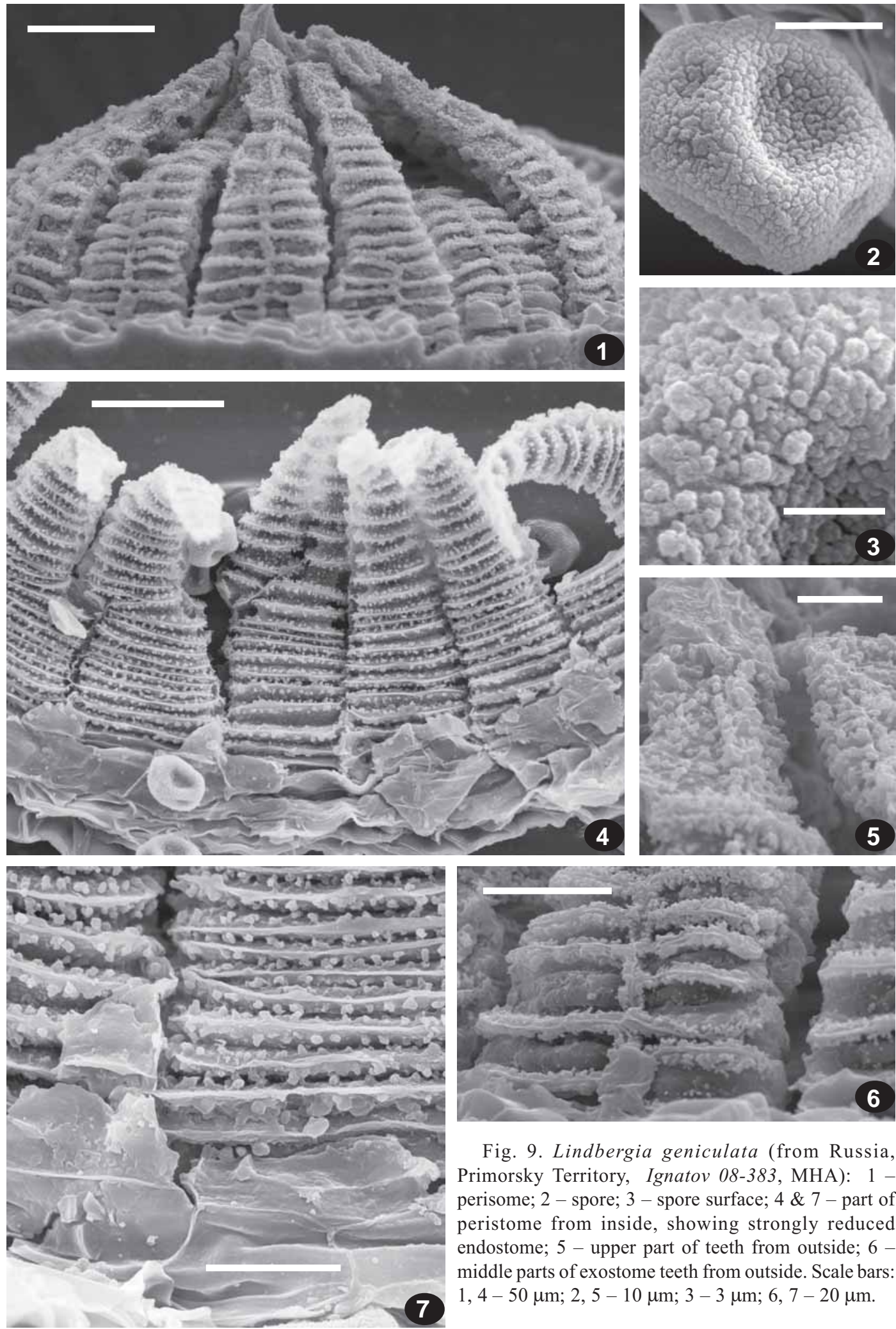

Fig. 9. Lindbergia geniculata (from Russia, Primorsky Territory, Ignatov 08-383, MHA): 1 perisome; 2 - spore; 3 - spore surface; 4 \& 7 - part of peristome from inside, showing strongly reduced endostome; 5 - upper part of teeth from outside; 6 middle parts of exostome teeth from outside. Scale bars: $1,4-50 \mu \mathrm{m} ; 2,5-10 \mu \mathrm{m} ; 3-3 \mu \mathrm{m} ; 6,7-20 \mu \mathrm{m}$. 

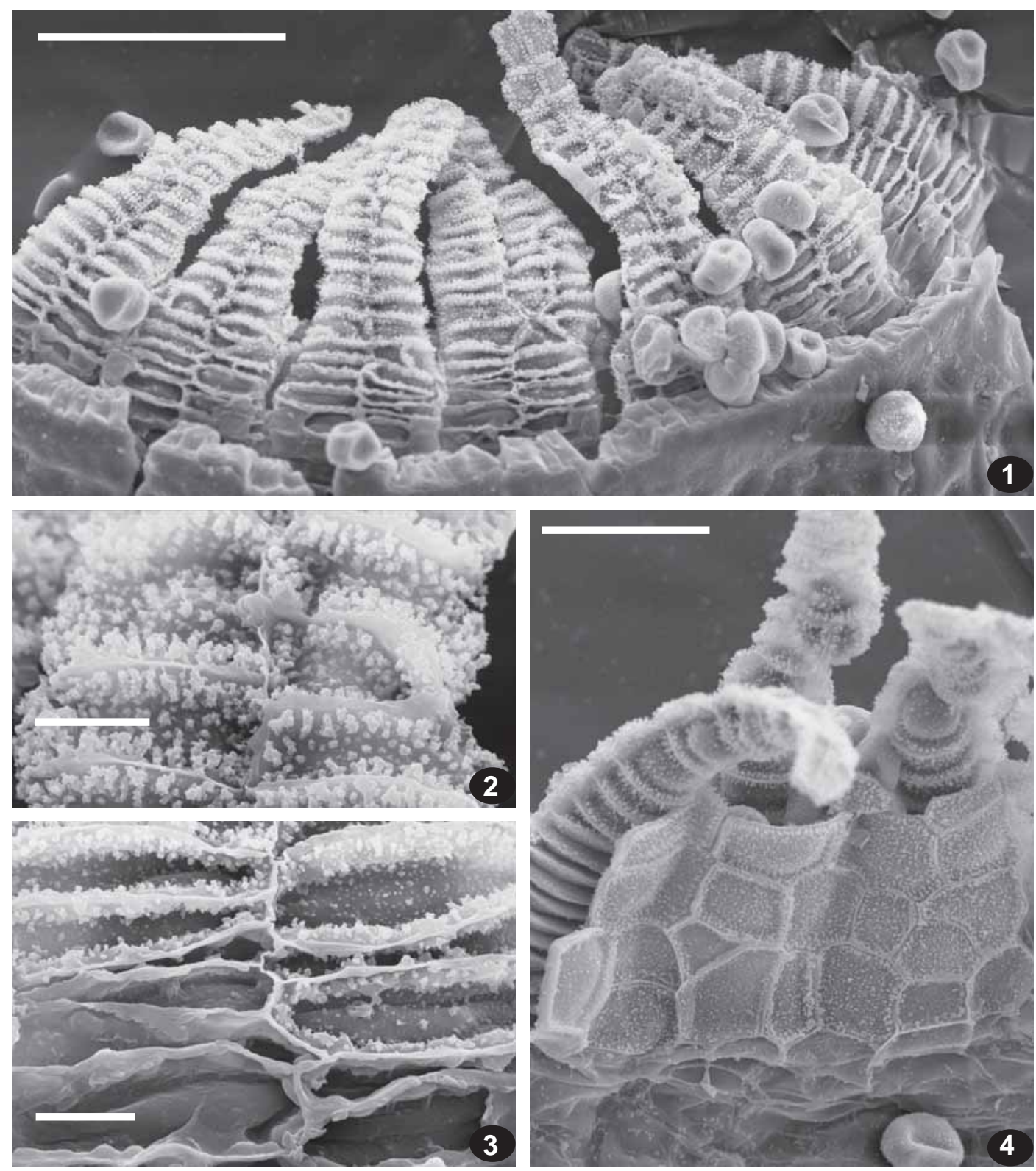

Fig. 10. Lindbergia sinensis (from Russia, Primorsky Territory, Ignatov 08-257, MHA): 1 - part of peristome from outside; 2 - outer surface of exostome tooth above the middle; 3 - outer surface of exostome tooth near base; 4 - peristome from inside, showing strongly papillose teeth and endostome reduced and represented by the basal membrane only, the latter being papillose and lacking segments. Scale bars: $1-100 \mu \mathrm{m} ; 2-3-10 \mu \mathrm{m} ; 4-$ $50 \mu \mathrm{m}$.

Fig. 11 (opposite page). 1-5 - Lindbergia dagestanica (from type: Russia, Dagestan, Samsel, \#119, MW); 6-7 L. patentifolia (from South Africa, Phephu \#28, H): 1 - peristome; 2 - outer surface of exostome teeth in the middle; 3,6, 7 - outer surface of exostome tooth at base (3 - high dorsal (sic!) trabeculae); 4 - outer surface of exostome tooth in distal part; 5 - part of peristome, showing lateral view of exostome tooth (note smooth and strongly incrassate ventral trabeculae), almost smooth basal membrane and moderately developed segment. Scale bars: $1-50 \mu \mathrm{m} ; 2,5-7-20 \mu \mathrm{m} ; 4-10 \mu \mathrm{m} ; 3-5 \mu \mathrm{m}$. 

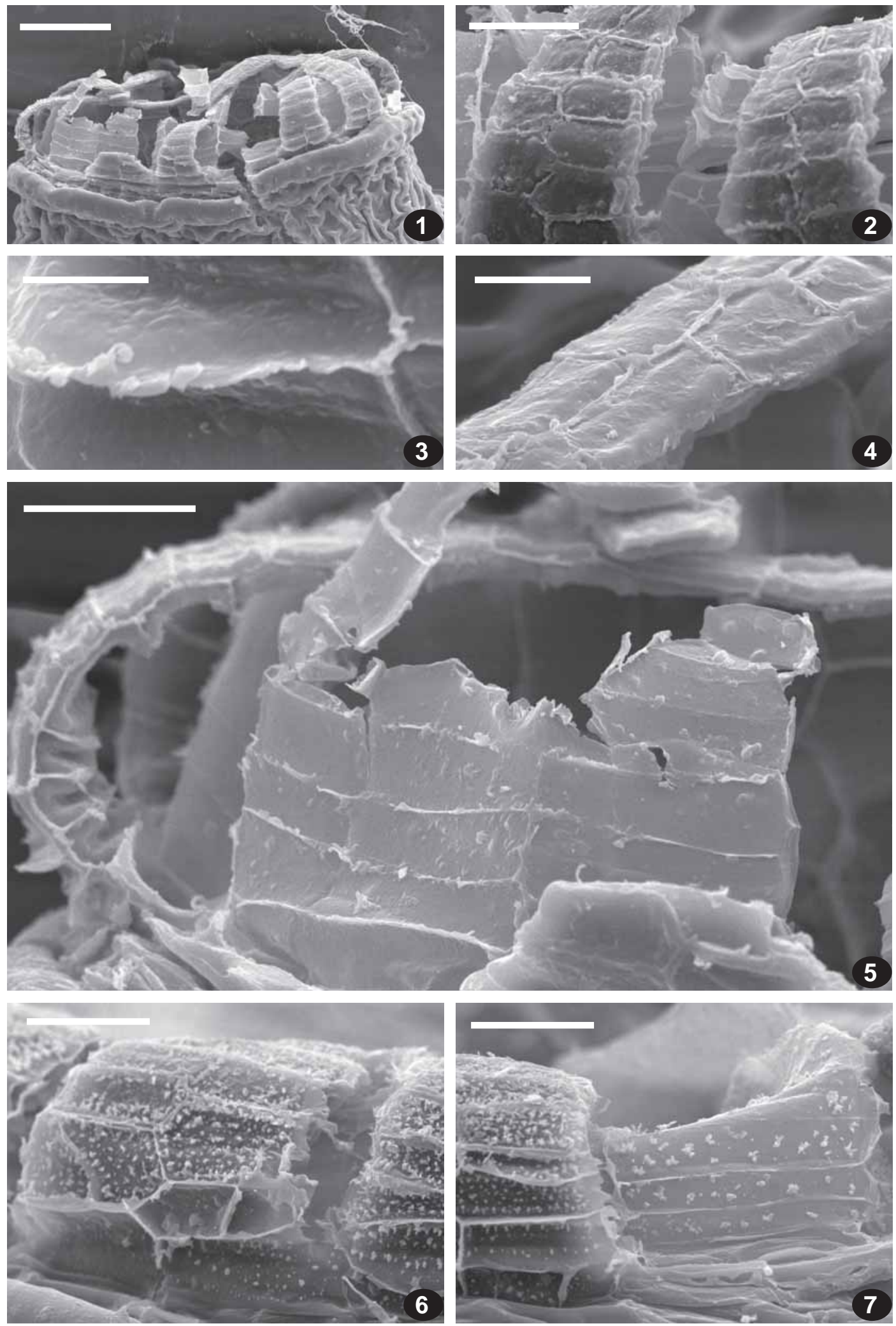

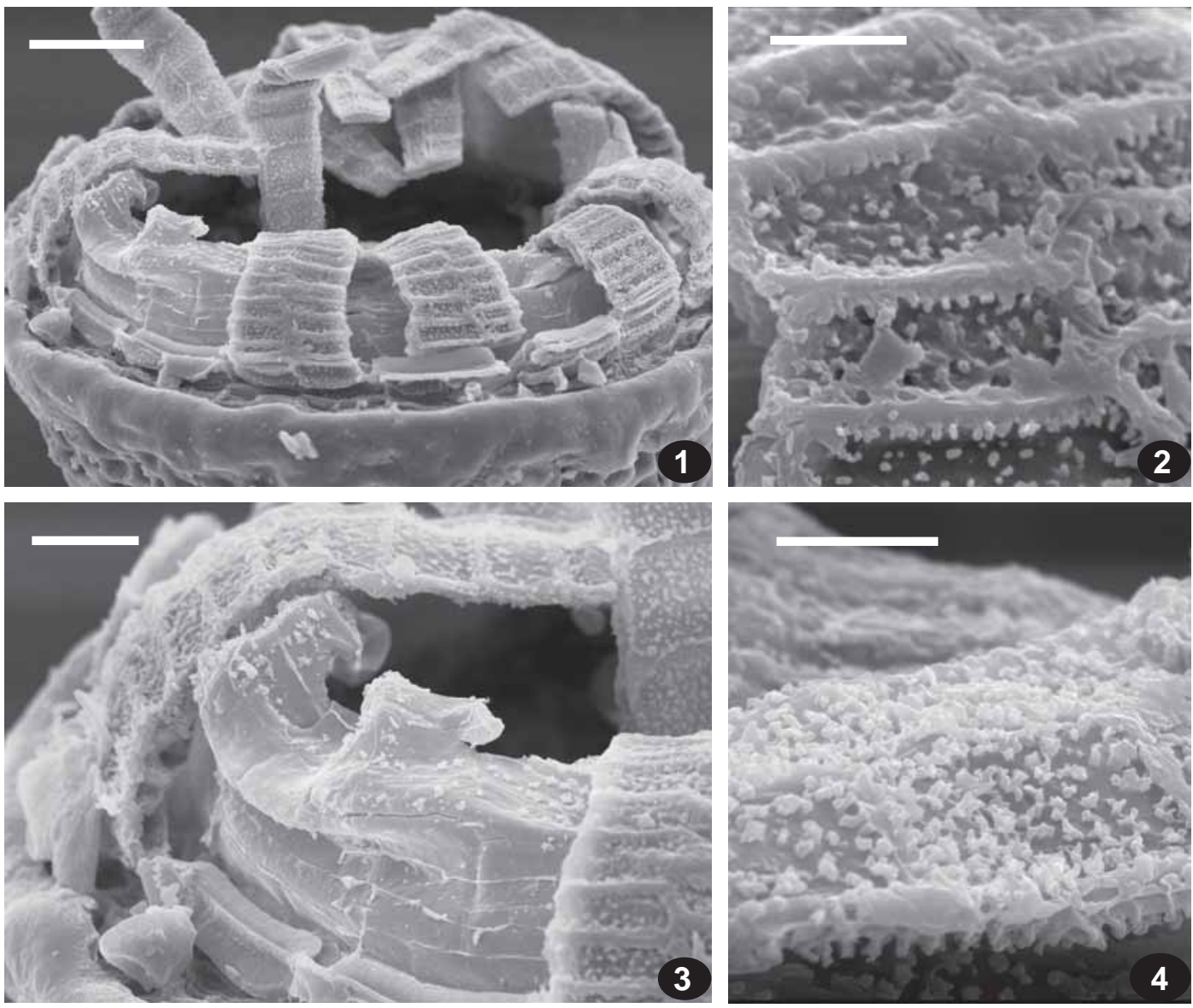

Fig. 12. Lindbergia mexicana (from Bolivia, Churchill \#24643, MHA ex MO): 1 - peristome; 2 - outer surface of exostome tooth in the middle; 3 - part of peristome, showing lateral view of exostome tooth; note papillose and only moderately incrassate ventral trabeculae, slightly papillose basal membrane and strongly reduced segments; 4 outer surface of exostome tooth distally. Scale bars: $1-50 \mu \mathrm{m} ; 3-20 \mu \mathrm{m} ; 2,4-10 \mu \mathrm{m}$.

Appendix 1. Taxon sampling and Genbank accession numbers (continued from p. 111).

P. nervosa (Brid.) Loeske

Pseudoleskeopsis imbricata (Hook. \& Wilson) Thér.

P. zippelii (Dozy \& Molk.) Broth. 1

P. zippelii (Dozy \& Molk.) Broth. 2

P. zippelii (Dozy \& Molk.) Broth. 3

Rauiella fujisana (Paris) Reimers 2

Rauiella fujisana (Paris) Reimers 1

Sanionia uncinata (Hedw.) Loeske

Sasaokea aomoriensis (Paris) Kanda

Thuidium assimile (Mitt) A. Jaeger

T. cymbifolium (Dozy \& Molk.) Dozy \& Molk.

T. delicatulum (Hedw.) Bruch \& al.

T. glaucinoides Broth.

T. kanedae Sakurai

T. pristocalyx (Müll. Hal.) A. Jaeger

T. tamariscinum (Hedw.) Bruch et al.

T. thermophilum Czernyadjeva

$\begin{array}{lll}\text { AF516167 } & \text { AF516152 } & \text { AY527135 } \\ \text { AY693653 } & \text { AY693653 } & \text { AY683581 } \\ \text { AY568548 } & \text { AY568548 } & \\ \text { FM161206 } & \text { FM161206 } & \\ & & \text { AY683603 } \\ & & \text { AY683600 } \\ \text { AY568546 } & \text { AY568546 } & \\ \text { AF168148 } & \text { AF168148 } & \text { AY009860 } \\ & & \text { JF280981 } \\ \text { AJ416442 } & \text { AJ416442 } & \\ \text { AY568542 } & \text { AY568542 } & \end{array}$

AY568544 AY568544

AY568541 AY568541

AY568540 AY568540

EF368013 EF368013 EF368012 